Article

\title{
Museums, Diasporas and the Sustainability of Intangible Cultural Heritage
}

\author{
Saphinaz-Amal Naguib \\ Department of Culture Studies and Oriental Languages, Oslo University, Oslo 0315, Norway; \\ E-Mail: s.a.naguib@ikos.uio.no; Tel.: +47-228-549-33; Fax: +47-228-548-28
}

Received: 2 April 2013; in revised form: 23 April 2013/ Accepted: 6 May 2013/

Published: 13 May 2013

\begin{abstract}
This article is about the work of museums in constructing the intangible cultural heritage of migration and diasporas. I address the cultural dimension of sustainability and examine what happens to living traditions in migratory contexts, in particular, in contexts of international migrations, and consider different participatory approaches used by museums. I propose that collaborative projects drawing upon the principles of ecomuseology and what I describe as participation by endowment may provide new ways of involving groups of immigrant background. I limit the discussion to questions tied to the intangible cultural heritage of migration to Europe and argue that by recording, documenting, safeguarding and keeping the intangible heritage of diasporas alive, museums contribute in promoting self-esteem among these populations and social cohesion in society.
\end{abstract}

Keywords: sustainability; culture diversity; intangible cultural heritage; museums; migration; diaspora; participation; endowment

\section{Introduction}

Heritage continues to be deeply tied to perceptions about nationhood, authenticity and deep, enduring roots that were developed during the 19th century [1-3]. It is considered a legacy that is defined by the spiritual and documentary importance of the objects, their economic value, as well as by their emotional significance and the memories they trigger. During the last three decades of the 20th century, these ideas have been challenged by complex and often dissonant understandings of identity or, rather, identities and polyphonic collective memories. The ensuing contentions emphasize that heritage is always tied to politics and power; to who decides what is worth being conferred upon the status of heritage, what is not heritage and why [4,5]. Today, heritage, whether it is classified as 
tangible or intangible cultural heritage or natural heritage, has become a major cultural resource and programs of sustainable development among which sustainable tourism and innovative industries greatly relying on the commodification of heritage are main assets. This is not only done by protecting monuments in danger, renovating buildings, gentrifying ancient urban districts, but also by supporting various bodies of local knowledge, occupational skills, crafts and traditions. Museums play a significant role in collecting, recording, safeguarding and exhibiting this heritage in its different forms.

In the present article, I propose to go beyond the narrow territorial associations tied to heritage and to include populations on the move in the heritage discourse. I consider the work of museums in constructing and integrating the heritage of migration and diasporas as part of the national heritage. Concentrating on intangible cultural heritage, I address the cultural dimension of sustainability and ponder on ways to avoid the fossilization of living traditions and "enskilled" knowledge in migratory contexts, in particular, in contexts of international migrations, when they are put in museums. I then present different participatory approaches and methods of display museums of cultural history engage with to safeguard and keep the intangible heritage of migration and diasporas alive. I suggest that collaborative projects inspired by ecomuseology and what I call participation by endowment may provide new ways of involving groups of foreign backgrounds in their museological projects. My examples are taken from museums in London, Paris and Oslo. The reasons for my choice of museums are quite simple. The London Museum opened the way to representations of migrations and diasporas in 1993. It remains a major reference and example for successive exhibitions on migration and diasporas arranged elsewhere. The Cité nationale de l'histoire de l'immigration in Paris was inaugurated in October 2007 after many years of hefty debates in the country. The reception has been mitigated, and the museum is still not completely integrated in the Parisian museumscape. As for Norway, minorities and the notion of diversity have been at the center of many political discussions during the last thirty years or so. In Oslo, where about $30 \%$ of the population is of foreign origin, museums have been at the forefront in taking up this topic in their exhibition programs [6-9].

\section{Enduring Heritage}

There are, according to Simona Bodo, two main approaches to heritage in museums [10]. One is the "essentialist" model, which considers heritage as unchangeable, permanent and, strongly inspired by the UNESCO Convention of 1972, imbued with a universal outstanding value [11]. The other approach is based on a "dialogical paradigm" that sees material and immaterial cultural heritage from a processual stance. This line entails not merely the protection and transmission of heritage, but in addition, brings forth questioning, renegotiations, alternative interpretations and also considerations on sustainability understood here as an on-going process of social and cultural learning. Culture, as Jon Hawkes advocated, constitutes the "fourth pillar" to sustainable development in addition to the economic, social and environmental ones [12,13]. Thus, besides always keeping the "well-being" of communities in focus, adding the cultural dimension to sustainability acknowledges the significance of more immaterial values that are related to notions of identity, different bodies of knowledge and ways of enduring while changing [14].

UNESCO has classified heritage into three distinct groups: tangible cultural heritage, natural heritage and, from 2003, intangible cultural heritage (ICH). Initiatives to protect ICH are continuously 
introduced to ward off the disappearance of living traditions and protect them from the threats of globalization, migration and the homogenization of cultures [15-17]. The fact that more than one hundred member states from countries in the North, as well as the South have today ratified the 2003 Convention for the Safeguarding of Intangible Cultural Heritage (hereafter 2003 Convention) indicates the popularity of a more holistic and inclusive perception of heritage. Measures in view to finance the maintenance of rituals and various bodies of knowledge, occupational skills and arts that are transmitted orally, by gesture or by examples, are being adopted by several nation-states, and there is a strong competition to have elements of the national ICH nominated on UNESCO's list of World Intangible Cultural Heritage. The actual implementations of these measures have not always been successful. To delve into these questions would, however, largely exceed the purpose of the present article. I therefore refer to some of the studies on the subject $[18,19]$ and turn instead to the much quoted and discussed article of the 2003 Convention.

Article two of the 2003 Convention states that:

The "intangible cultural heritage" means the practices, representations, expressions, knowledge, skills-as well as the instruments, objects, artefacts and cultural spaces associated therewith-that communities, groups and, in some cases, individuals recognize as part of their cultural heritage. This intangible cultural heritage, transmitted from generation to generation, is constantly recreated by communities and groups in response to their environment, their interaction with nature and their history, and provides them with a sense of identity and continuity, thus promoting respect for cultural diversity and human creativity. For the purposes of this Convention, consideration will be given solely to such intangible cultural heritage as is compatible with existing international human rights instruments, as well as with the requirements of mutual respect among communities, groups and individuals, and of sustainable development [20].

The 2003 Convention is somehow unclear regarding the communities involved and the stakeholders. These were specified at the meeting arranged by the Intangible Heritage Section of UNESCO and the Asia/Pacific Cultural Centre for UNESCO in Tokyo in 2006. Three main groups of stakeholders were listed:

(1). Specific communities considered to form networks of people whose sense of identity or connectedness is tied to a shared history based on the practice and transmission of or engagement with their ICH.

(2). Groups of people within or across communities who share characteristics, such as skills, experience and special knowledge, and play important roles in the present and future practice, re-creation and/or transmission of their intangible cultural heritage.

(3). Individuals within or across communities with specific skills, knowledge, experience or other attributes.

In addition to these three groups, the meeting added "society", referring to the whole population of a country and "multinational" or "scattered communities/groups", who are attached to a single heritage that is not bound to a single geographical area or country [21]. The latter addition opens up for including migrants and diasporas in the ICH discourse. 
People are the focal point in ICH, as it is mostly based on intergenerational transmission and "enskilled" knowledge, that is, knowledge acquired by practice and experience [22,23]. Hence, ICH encompasses cultural and social practices, ceremonies, various forms of arts and crafts, places, as well as occupational skills. The notion of safeguarding is central to intangible cultural heritage. It conveys the idea of protecting and preserving, while at the same time transmitting far and wide. It "means measures aimed at ensuring the viability of the intangible cultural heritage, including the identification, documentation, research, preservation, protection, promotion, enhancement, transmission, particularly through formal and non-formal education, as well as the revitalization of the various aspects of such heritage" [24]. Today, the viability and sustainability of the ICH depends largely on financial resources to support it. It implies, among other things, reaching wider audiences and that the transmission of the ICH is open to communities and groups beyond closed ethnic, religious or national circles and networks. That is, in my view, where museums of cultural history can play an important role. Many ethnographic museums have already revised their museological approaches in their representations of other cultures in order to avoid their essentialization and exotification. Other museums, like folk museums and city museums, are introducing ecomuseological perspectives by actively involving members of the different communities and groups, also immigrants and diasporas, in their projects [25-27].

The commitment to sustainability is not without inconsistencies, and there is an increased awareness that tangible and intangible forms of cultural heritage are tightly interwoven. This has led several specialists in the field to question the implications of the ICH discourse. For them, cultural heritage should be perceived in terms of what Kirschenblatt-Gimblett [28,29] defines as a "metacultural production", underlining by that the economic significance cultural heritage in its multifarious forms of expression has in the different countries and among various communities and groups [30]. One has to keep in mind the strong intertwinement between the tangible and the intangible and that the intangibility of cultural heritage is articulated through the materiality of culture. Conversely, in the words of Dawson Munjeri "the tangible can only be understood and interpreted through the intangible" [31]. In exhibitions about migration and diaspora, the interdependence between tangible and intangible cultural heritage is often conveyed through objects of everyday life, such as delicately embroidered clothes or tablecloths, lace curtains, handcrafted objects, religious artefacts, musical instruments, books or calligraphed manuscripts. These items that migrants have brought with them from "home" express practices and forms of knowledge that are strongly tied to a sense of identity, to place and to memory.

Cultures never stand still; they are continuously in the making [32]. Accordingly, as a "metacultural product", intangible heritage is attuned to changes in society, the entanglement of multiple identities and to the effects of glocalization. In her analyses of the growing attention to the significance of intangible cultural heritage within UN cultural policies, Marilena Alivizatou examines the implications it has both on the international level and in practice on the local level in museums. She points out that one of the main paradoxes proposed by UNESCO and other international and national organizations is to implement measures in "making the impermanent permanent" [33]. For museums of cultural history, it means that they need to expand on their traditional obligations of collecting, recording, safeguarding, exhibiting and educating and to elaborate new visions and methods to their museology of intangible heritage. It involves also finding ways of including the intangible heritage of minorities, 
whether they are indigenous, national or of foreign origin, into the broader one of the nation state. Recognition and respect for cultural diversity are the first steps in that direction.

\section{Acknowledging Cultural Diversity}

Charles Taylor begins his famous essay The Politics of Recognition by stating that identity and recognition or the absence of recognition-misrecognition-, are tightly entangled. Misrecognition, he posits, has been used as a weapon of oppression that has often been internalized by subaltern groups and led to the depreciation of their own cultures, traditions and local knowledge [34]. In a number of countries in Europe, efforts have been made towards indigenous people and national minorities who have consequently obtained the recognition of their rights. Several museums of cultural history have been attuned to these shifts and become important actors in what could be described as the politics of inclusion of these groups. Accordingly, they have introduced a museology of polyphonic narratives and intersecting gazes to give voice to the multiple, often conflicting, stories of the different nation states [35-37]. Immigrants, especially those arriving from countries in the South, are, however, still on the margin of society and, thus, not at the center of museums' programs. As I use it here, the generic term immigrant covers exiles, refugees, asylum seekers and expatriates who have left their countries of origin for various reasons and settled elsewhere. Some have stayed in the host country for generations and become part of a given diaspora.

A number of scholars have noted that the semantic value of the term diaspora has inflated during the last thirty years or so. It refers now to various types of migrant communities and displaced populations, so as to reflect various intellectual, cultural and political agendas [38]. Generally speaking, diasporas retain three main characteristics that are more or less highlighted according to the surrounding actual situations. These are their dispersion in space, their orientation to a conceptual center and the maintenance of borderlines separating them from "others". According to James Clifford, diaspora combines perceptions of "roots and routes". It evokes a separation similar to that of exile and entails to live somewhere while continuing to belong to a scattered population elsewhere. Hence, diasporic cultures and discourses are embedded in transnational belonging and networks and strive to harmonize between "separation and entanglement" $[39,40]$. This does not go without tensions, and the idea of undying territorial and ethnic roots and identities often pressures individuals into the constraining molds of "sameness-in-dispersal" [41]. Diasporas may also be heterogeneous, hence, transethnic, transreligious and transnational. They may, for instance, consist of racial groups, linguistic groups or religious groups. Actually, diasporas exemplify the polysemy and hybridity of "imagined communities". They convey the idea of a composite, enduring sameness in shifting contexts; an endeavor to maintain the integrity and authenticity of one's heritage, may it be linguistic, cultural or religious, while, at the same time, accommodating changes.

As noted above, the 2003 Convention states the respect for cultural diversity and the recognition of the legitimacy of different cultural values as fundamental dimensions of IHC. The notion of cultural diversity encompasses a great number of complex issues pertaining to ethnicity, religion, social class, gender, education and economy. For museums, it entails, among others, to experiment with new approaches in representing similarities and differences and in highlighting the benefits of cultural contacts, transculturality and cosmopolitanism, more specifically, for our purpose here, everyday 
cosmopolitanism. The term transculturality was introduced by Fernando Ortiz to express various stages of the process of transition from one culture to another [42]. As indicated by the prefix trans, transculturality conveys the idea of going beyond cultural boundaries. It requires the negotiation of difference and brings to mind images of cultural cross-fertilizations. Everyday cosmopolitanism takes us a step further. It is perceived as a state of mind, a way of managing and participating in a plurality of cultures on one's own terms. It requires a certain competence and an intellectual and aesthetic openness to different cultural experiences $[43,44]$. It presupposes selectivity and autonomy towards one's culture of origin. This does not mean the complete erasure of one's sense of belonging, but rather of widening it and accepting individual prismatic identities. All these processes involve openness to "bricolage", namely, of choosing and putting together in new ways. What is taken or abandoned depends on various factors tied to contexts, events and individual agency. Museums have in recent years been experimenting with ways of visualizing the intricacies of these modes of being among migrants and diasporas. The exhibition Hijab-the right to choose at the Oslo City Museum was an example of this trend $[45,46]$. The exhibition was set up at the time a heated debate about the use of the Islamic veil or hijab as part of the police uniform was going on in Norway. Despite a number of weaknesses in the museological approach, which I will not go into here, the exhibition succeeded, nevertheless, to convey the idea of complex identities among young women from the Muslim diaspora. It underscored their ability to improvise and innovate, while asserting their religious identity. The film made for the exhibition was an effective medium to communicate this message. It showed the participants to the project wearing the most recent models of what is today known as the "Islamic fashion" that is in vogue among women of the diaspora, as well as among young urban women in the Middle-East, North Africa and south Asia. In the film, the young heavily made-up Muslim women from the diaspora with their attractive and colorful head-covers and veils pacing the catwalk in tight-fitting clothes that revealed the curves of their bodies stood in strong contrast with the Norwegian female converts to Islam dressed in modest, wide clothes and heavy veils. Actually, as they were presented in the exhibition, the young women of the diaspora appeared to be completely in touch with the latest developments in what has become a transnational style and taste, as well as a way of being.

Immigrants do not arrive empty handed. They bring with them traditions, various types of knowledge and experiences that make up the core of their intangible cultural heritage. Trying to keep one's intangible cultural heritage alive in migratory and diasporic contexts does not mean immobility. The flow from one setting to another and the transmission and dissemination of this transferred knowledge entails a certain degree of re-interpretation and adaptation. Change is based on continuity and discontinuity, memory and amnesia. Hence, as a modality for transformation, transferred knowledge implies opening up for improvisation and innovation. For instance, dietary and culinary arts, rituals related to the cycle of life, celebrations like those tied to the spring festival of Nayruz that marks the New Year among many communities of Middle-Eastern origin or the Shi'a ceremonies of ta'aziya commemorating the martyrdom of Hussein, performative arts, medical practices like Chinese acupuncture and the Indian Ayurveda are attuned to new environments in order to live on through unceasing adjustments. Others are discarded and more or less forgotten, while others, again, as has been the case with the Chilean cueca dance during the government of Pinochet, are re-discovered and revitalized by Chilean exiles [47,48]. The different immigrant groups and diasporas act as milieux de mémoire or environments of memory to use the terminology of Pierre Nora [49]. As such, they are 
main actors to museums' collaborative projects and in helping them to construct a sustainable heritage of migration and diasporas.

\section{Participation and Collaborative Projects}

Participation is the new buzzword in the world of museums, and questions related to participation have primarily to do with social change and ideas about democracy. In her book Museums and the Public Sphere, Jennifer Barrett argues that in their interaction with their audiences, museums should consider the public sphere as a broad cultural sphere, a democratic public space that engages with a varied public rather than the bourgeois elite and literary public of Habermas [50,51]. An increasing number of museums of cultural history pursue today a politics of positioning and establish themselves in terms of "authorities of recognition" [52]. In order to reach these goals, they have, during the last two decades, organized "third spaces", where individuals and groups are given the opportunity of crossing the barriers of belonging and of sharing their knowledge, know-how and experiences across cultural divides [53]. These third spaces serve as "contact zones" to use the expression coined by Marie Louise Pratt and later taken up by James Clifford [54,55]. Not only do they provide the grounds for cultural encounters, but they also offer an environment of reflection where immigrants and diasporas can exchange views on the meaning and value of their heritage, on the worth of its sustainability and on ways of making this heritage known to wider audiences. One of the prevalent concerns in these museums is the management and implementation of various forms and objectives of audience participation. Audience participation in museums is very much inspired by management methods of outsourcing and the media's user-generated contend (UGC) and CNN's iReport, where the user, i.e., the audience, elaborates the substance and subject matter. Katherine Goodnow distinguishes four forms of participation in museums. These are: access, reflection, provision and structural involvement. All four bring out the significance of both museum and audiences' interests [56].

The first, participation at the level of access, goes from physical design with the provision of ramps and lifts, alternative maps to forms of storytelling that include braille, films, soundscapes, multimedia devices, information placed at differing heights and online. It also addresses access in relation to cost and whether museums should have free entrance, as well as developing outreach programs. The second, participation by reflection, stems from a shift in the museums' perception of their changing role in society and their need to attract diverse audiences and to retain their interest. Participation by way of provision involves community members. People from different backgrounds are asked to donate artefacts, memories and personal stories to enhance and add value to an exhibition or to make up the core of a program. For museums, these provisions serve several functions. Personal stories fill in the gaps of authorized narratives and, in addition, impart drama and an emotional effect to exhibitions. They may also bring some corrections to the curators' expertise and interpretation. Participation by provision has opened the way to structural involvement and the recognition of communities, groups and individuals as significant contributors to the main narrative of the nation. Both participation by way of provision and structural involvement are loosely inspired by principles of ecomuseology and the active commitment of communities. In practice, museums mix these two last approaches in what could be described as participation by endowment, that is, by making a donation that becomes a source of income for the museum. 
In his seminal work Essai sur le don, Marcel Mauss [57] examined how the exchange of objects between groups builds up relationships between them. He argued that in so-called archaic societies, gifts contribute in building up alliances and networks. This entails an obligation to give, to receive and, most importantly, to reciprocate. The gift according to Mauss rests on immaterial values that keep up relationships between people or groups. It involves reciprocity and an obligation to pay back a debt. An endowment is a gift to be fructified. It is normally made to an institutions or groups of individuals on the understanding that they will develop the fund for a stipulated period of time. Thus, there are strings attached to an endowment and the conditions that are set bind both the donor and the beneficiary. The bond between the two may be severed if the provisions of the endowment are not respected or in case of conflicts whether these are within the diasporic milieu, as it often happens or between members of a community and the museum. Endowments to museums can take different forms. They may, for instance, be tied to fundraising, bequeathing a private collection or to voluntary work of some sort.

In exhibitions treating migration and diasporas, participation by endowment is done by relying on donations or loans of different kinds of objects oral history, life stories and performance. The London Museum set the tone in 1993 with The Peopling of London. The exhibition showed that cultural diversity in London can be traced back to prehistoric times and brought to light the history of eighteen communities of foreign origin and their impact on the social, cultural and economic life of the city. The exhibition was conceived as a collaborative project where members of the different communities were consulted. Additionally, many of them complemented the material that was already in the museum's collections by lending some of their personal belongings to the exhibition. The pattern was developed further by the Cité nationale de l'histoire de l'immigration in Paris (CNHI), where the permanent exhibition, Repères, investigates the steps towards integration and assimilation by mixing history and memory [58]. The CNHI did not have a pre-existent collection and, therefore, depends largely on donations to build one up. So far, the collection consists of a mixture of tangible, intangible and e-tangible items, such as photographs, letters, objects and instruments used in daily life, as well as oral testimonials, personal videos and digital self-presentations. Different people recount snippets of their lives and share some of their experiences and knowledge with the public. The individual life stories are also available on the web-pages of the CNHI and may be accessed online. The section entitled Diversite shows the manifold contributions immigrants brought to French society. These go from objects of practical character, such as simple kitchen utensils to more sophisticated innovations in the industrial sector, to more immaterial items, such as contributions to the arts, literature, sports and cultural life. A table provided with screens invites visitors to discover how the French language has through centuries been enriched by the integration of foreign words. In the section called Gallerie des dons (Gallery of donations), we find identity papers, certificates and diplomas of individuals who have come to France from various parts of the world and at different periods. The explanatory texts provide biographical information about each person and place them within the wider geo-political and historical context of migration.

The Intercultural Museum (IKM), which is today a section of the Oslo Museum, offers another example of participation by endowment [59,60]. It was first used during the 1990s for the series of exhibitions related to ceremonies, traditions and practices related to the lifecycle from birth to death. Here, people from various ethnic and religious backgrounds came together to exchange their 
knowledge, know-how and experiences around these topics. The current exhibition Our Sacred Spaces, which introduces six religious communities in the counties of Oslo and Akershus, was also conceived by relying on the gift of such an intangible heritage as religion may represent. The aim of this exhibition is to show Norway's religious diversity and encourage dialogue and respect between people of different religions. Interactivity and performance are major characteristics of Our Sacred Spaces, and the visitors - mostly school children - take part in the scenography. They are, for instance, invited to take off their shoes, wash their hands, cover their heads, light candles, burn incense, write down their thoughts about love on a blackboard and reflect on the meaning of faith and belief $[61,62]$. The places of worship of the different religious communities represented in this exhibition have been exactly reproduced to scale. Photographs, texts and videos show how the rituals and religious celebrations are performed and also how they are adjusted to local contexts. For instance, a video in the section about Hinduism shows how the Tamil community of the Sivasubra Manyar Alam temple has adapted the ritual bathing of the deity during the Tiruvella festival to local environments by performing it in a nearby lake.

\section{Concluding Remarks}

Once in the museum, the intangible heritage of migration and diasporas risks petrification and, thus, loses some of its fundamental dimensions, namely, improvisation and adaptation. For instance, the video showing the Tiruvella festival was shot several years ago and has been shown since; any changes brought to the ritual during that time have gone unrecorded. To avoid these kinds of discrepancies and in order to keep the intangible heritage alive, museums, such as the CNHI and IKM, try out different approaches borrowed from ecomuseology and organize various activities and events in the form of lectures, creative workshops for adults and children, concerts, theatre and dance performances. This is usually done in connection with special venues related, for instance, to the presence of touring artists, performing groups and to new exhibitions. Performance in museums entails displaying various forms of knowledge, know-how, arts and crafts in re-created cultural contexts [63]. Accordingly, a traditional kathak dance from India, a classical maqam concert or a Mevlevi Sema ceremony from Turkey have to be choreographed so as to suit the setting of the museum in regard to a more restricted time to perform in, the space of the stage and also audience behavior.

Extending the idea of the gift to museums and to participation by endowment, we may infer that by donating various kinds of objects, their life stories and sharing their living traditions, knowledge, practices and experiences individuals of immigrant and diasporic milieus provide the basis on which the intangible cultural heritage of migration and diasporas is being shaped. In addition, they enrich the collections that are kept in the museum and contribute to reaching out to a broader audience. Thus, they bind and bound these institutions and have an impact on the host country's politics of integration. Conversely, in addition to prompting self-esteem and a sense of pride about one's cultural background, museums give immigrants and diasporas the means to re-appropriate their own cultures and to transform their living traditions and enskilled knowledge into intangible heritage. For the younger generation, such events may (re)connect them with the ICH of their families and countries of origin. However, in order to enhance and safeguard the sustainability of that heritage, museums have to be attentive to the ways this intangible heritage is redefined to suit new environments. They have to 
continuously assess whether its viability as a vehicle of social and cultural learning has any significance for a community or if, in reality, it signifies a process of essentialization and a door towards the commodification of heritage

Participation by endowment has, as mentioned earlier, its limitations. These have to do with internal conflicts in the diasporic milieus, institutional restricted economies and broader political realities. Further, donors may contest the manner in which their gifts are being used in an exhibition or the museum may find the interference of donors deterrent to the realization of their plans. To avoid any misunderstandings in their collaborative projects, museums ought to clarify the premises on which they are built. Ultimately, it is the museum who sets the structure on which to construct the heritage of migration and diasporas and who decides on its sustainability.

\section{Conflict of Interest}

The author declares no conflict of interest.

\section{References and Notes}

1. Babelon, J.-P.; Chastel, A. La Notion de Patrimoine (in French); Liana Levi: Paris, France, 1994.

2. Lowenthal, D. The Past is a Foreign Country; Cambridge University Press: Cambridge, UK, 1985.

3. Lowenthal, D. The Heritage Crusade and the Spoils of History; Viking: London, UK, 1997.

4. Smith, L. The Uses of Heritage; Routledge: London, UK, 2006.

5. Ashworth, G.J.; Graham, B.; Turnbridge, J.E. Pluralising Pasts: Heritage, Identity and Place in Multicultural Societies; Pluto Press: London, UK, 2007.

6. Merriman, N. The Peopling of London: Fifteen Thousand Years of Settlement from Overseas; The Museum of London: London, UK, 1993.

7. Naguib, S.A. Reconciling History and Memory at the Cité Nationale de l'Histoire de l'Immigration in Paris. In Museums, New Media and Refugees: Forms and Issues of Participation; Skartveit, H., Goodnow, K., Eds.; Berghahn Books: New York, NY, USA, 2010; pp. 47-58.

8. Innvandrere og norskfødte med innvandrerforeldre, 1.januar 2013. Available online: http://www.ssb.no/befolkning/statistikker/innvbef/ (accessed on 24 April 2013).

9. Innvandring 2012. Available online: http://www.utviklings-og-kompetanseetaten.oslo. kommune.no/oslostatistikken/innvandring/ (accessed on 24 April 2013).

10. Bodo, S. Museums as Intercultural Spaces. In Museums, Equality and Social Justice; Sandell, R., Nightingale, E., Eds.; Routledge: London, UK, 2012; pp. 181-191.

11. Article 1 of the UNESCO Convention Concerning the Protection of the World Cultural and Natural Heritage of 1972. Available online: http://whc.unesco.org/en/conventiontext/ (accessed on 24 April 2013).

12. The Fourth Pillar of Sustainability: Culture's Essential Role in Public Planning. Available online: http://www.culturaldevelopment.net.au/community/Downloads/HawkesJon(2001)TheFourthPillar OfSustainability.pdf (accessed on 24 April 2013).

13. Culture as the Fourth Pillar of Sustainable Development. Available online: http://www.fao.org/ sard/common/ecg/2785/en/Cultureas4thPillarSD.pdf (accessed on 24 April 2013). 
14. Duxbury, N.; Gillette, E. Culture as a Key Dimension of Sustainability: Exploring Concepts, Themes, and Models. Available online: http://cultureandcommunities.ca/downloads/WP1Culture-Sustainability.pdf (accessed on 24 April 2013).

15. The World Heritage Convention (WHC) of 1972 included tangible heritage and natural heritage. Available online: http://whc.unesco.org/en/about/ (accessed on 24 April 2013).

16. UNESCO World Heritage Centre. Available online: http://whc.unesco.org/en/list (accessed on 24 April 2013).

17. The Convention for the Safeguarding of the Intangible Cultural Heritage (ICH) was established in 2003. Available online: http://www.unesco.org/culture/ich/index/ (accessed on 24 April 2013).

18. Kurin, R. Safeguarding Intangible Cultural Heritage: Key factors in Implementing the 2003 Convention. IJIH 2007, 2, 10-20.

19. Smith, L., Akagawa, N., Eds. Intangible Heritage; Routledge: London, UK, 2009.

20. Text of the Convention for the Safeguarding of Intangible Cultural Heritage. Available online: http://www.unesco.org/culture/ich/index.php?lg=en\&pg=00006/ (accessed on 24 April 2013).

21. Cang, V.G. Defining Intangible Cultural Heritage and its Stakeholders: The Case of Japan. IJIH 2007, 2, 46-55.

22. Stefano, M.L.; Davies, P.; Corsane, G. Touching the Intangible:An Introduction. In Safeguarding Intangible Cultural Heritage; Stefano, M.L., Davis, P., Corsane, G., Eds.; The Boydell Press: Woodbridge, UK, 2012; pp.1-5.

23. Ingold, T. Making Culture and Weaving the World. In Matter, Materiality and Modernity Culture; Graves-Brown, P., Ed.; Routledge: London, UK, 2000; pp. 50-71.

24. Convention for the Safeguarding of the Intangible Cultural Heritage. Available online: http://unesdoc.unesco.org/images/0013/001325/132540e.pdf (accessed on 24 April 2013).

25. Alivizatou, M. Intangible Heritage and the Museum; Critical Cultural Heritage Series; Left Coast Press Inc.: Walnut Creek, CA, USA, 2012.

26. Macdonald, S. Memorylands. In Heritage and Identity in Europe Today; Routledge: London, UK, 2013.

27. Naguib, S.-A. The One, the Many and the Other. Revisiting Cultural Diversity in Museums of Cultural History. In National Museums in a Global World; NaMu III, 2007; Linköping University Electronic Press: Linköping, Sweden, 2007; pp. 5-19. Available online: http://www.ep.liu.se/ecp/ 031/001/ecp0703101.pdf (accessed on 24 April 2013).

28. Kirschenblatt-Gimblett, B. Intangible Heritage as Metacultural Production. Museum International 2004, 56(1-2), 52-65.

29. Kirschenblatt-Gimblett, B. World Heritage and Cultural Economics. In Museums Frictions: Public Cultures/Global Transformations; Karp, I., Kratz, C., Szwaja, L., Ybarra-Frausto, T., Eds.; Duke University Press: Durham, UK, 2006; pp. 161-203.

30. Ruggles, D.F.; Silverman, H. From Tangible to Intangible Heritage. In Intangible Heritage Embodied; Ruggles, D.F., Silverman, H., Eds.; Springer: Dordrecht, Germany, 2009; pp. 1-14.

31. Munjeri, D. Tangible and Intangible Heritage: from Difference to Convergence. Museum International 2004, 56, 12-20. 
32. Naguib, S.-A. The Temporalities of Cultural Memory. In Moving Matters/Ethnoarchaeology in the Near East; Wendrich, W., van der Kooij, G., Eds.; Research School of Asian, African, and Amerindian Studies, Universiteit Leiden: Leiden, The Netherlands, 2002; pp. 181-187.

33. Alivizatou, M. The Paradoxes of Intangible Heritage. In Safeguarding Intangible Cultural Heritage; Stefano, M.L., Davis, P., Corsane, G., Eds.; The Boydell Press: Woodbridge, UK, 2012; pp. 9-21.

34. Taylor, C. The Politics of Recognition. Available online: http://elplandehiram.org/documentos/ JoustingNYC/Politics_of_Recognition.pdf (accessed on 24 April 2013).

35. Naguib, S.-A. The Aesthetics of Otherness in Museums of Cultural History. Tidskrift for kulturforskning 2004, 3, 5-21.

36. Naguib, S.-A. Autres temps, autres regards: Représentations de l'altérité au musée d'Histoire culturelle de l'université d'Oslo (in French); Histoire de l'art: Paris, France, 2007; pp. 49-160.

37. Naguib, S.-A. Representasjoner av kulturmangfold i kulturhistoriske museer. In Samling og museum. Kapitler av Museenes Historie, Praksis og Ideology (in Norwegian); Rogan, B., Amundsen, A.B., Eds.; Novus Forlag: Oslo, Norway, 2010; pp. 277-293.

38. Brubaker, R. The “diaspora” diaspora. Ethnic Racial Studies 2005, 28, 1-19.

39. Clifford, J. Diasporas. Cultural Anthropology 1994, 9, 302-338.

40. Clifford, J. Routes: Travel and Translation in the Late Twentieth Century; Harvard University Press: Cambridge, MA, USA, 1997; pp. 244-277.

41. Ang, I. On Not Speaking Chinese. In Living between Asia and the West; Routledge: London, UK, 2001; p. 13.

42. Ortiz, F. Cuban Counterpoint: Tobacco and Sugar; Duke University Press: Durham, UK, 1995.

43. Hannerz, U. Transnational Connections: Culture, People, Places; Routledge: London, UK, 1996.

44. Vertovec, S., Cohen, R., Eds. Conceiving Cosmopolitanism:Theory, Context, and Practice; Oxford University Press: Oxford, NY, USA, 2002.

45. Hijab-med rett til å velge. Available online: http://www.oslomuseum.no/ (accessed on 24 April 2013).

46. Naguib, S.-A. Engaging with Gender and Diversity in Museums of Cultural History. ARV Nordic Yearbook Folklore 2011, 67, 111-128.

47. Naguib, S.-A. Mosques in Norway. In The Creation and Iconography of Sacred Space; Novus forlag: Oslo, Norway, 2001; The Institute of Comparative Research in Human Culture, serie B: Skrifter CVII; pp. 88-94.

48. Knudsen, J.S. Traditional Dance in the Immigrant Community-A Chilean Example. In Meetings at the Crossroads. Studies of Multilingualism and Multiculturalism in Oslo and Utrecht; Hvenekilde, A., Nortier, J., Eds.; Novus forlag: Oslo, Norway, 2001; pp. 329-340.

49. Nora, P. Entre mémoire et histoire: La problématique des lieux de mémoire (in French). In Les lieux de mémoire; Nora, P., Ed.; Gallimard: Paris, France, 1984; pp. xvii-xlii.

50. Barett, J. Museums and the Public Sphere; Wiley-Blackwell: Chichester, UK, 2011.

51. Habermas, J. The Structural Transformation of the Public Sphere: An. Inquiry into a Category of Bourgeois Society; MIT Press: Cambridge, MA, USA, 1989.

52. Feuchtwang, S. Loss, Transmissions, Recognitions, Authorisations. In Regimes of Memory; Radstone, S., Hodgins, K., Eds.; Routledge: London, UK, 2003; pp. 76-89. 
53. Watson, S., Ed. Museums and their Communities; Leicester's Readers in Museum Studies; Routledge: London, UK, 2007.

54. Pratt, M.L. Imperial Eyes: Travel and Translation; Routledge: London, UK, 1992.

55. Clifford, J. Routes: Travel and Translation in the Late Twentieth Century; Harvard University Press: Cambridge, MA, USA, 1997; pp.188-219.

56. Goodnow, K. Introduction: Expanding the Concept of Participation. In Changes in Museum Practice: New Media, Refugees and Participation; Skartveit, H.-L., Goodnow, K., Eds.; Berghahn Books: New York, NY, USA, 2010; pp. xxv-xxxviii.

57. Mauss, M. Essai sur le don. Forme et raison de l'échange dans les sociétés archaïques. Available online: http://philo-online.com/TEXTES/MAUSS\%20-\%20Essai\%20sur\%20le\%20don.pdf (accessed on 24 April 2013).

58. Cité nationale de l'histoire de l'immigration. Available online: http://www.histoireimmigration.fr/musee/ (accessed on 24 April 2013).

59. Oslo Museum. Available online: http://www.oslomuseum.no/ (accessed on 24 April 2013).

60. Naguib, S.-A. La poétique de la diversité dans un musée sans collection. (in French). In Transmission, Invention: Le Renouveau des Musées de Civilisations; Chevallier, D., Ed.; Éditions Documentation Française: Paris, France, 2013.

61. The exhibition opened in 2007 and has since been prolonged several times. The new closing date is set to the end of December 2013.

62. Varutti, M. Gradients of Alterity: Museums and the negotiation of cultural difference in contemporary Norway. Arv. Nordic Yearbook Folklore 2011, 67, 13-36.

63. Jackson, A.; Kidd, J. Introduction. In Performing Heritage: Research, Practice and Innovation in Museum Theatre and Live Interpretation; Jackson, A., Kidd, J., Eds.; Manchester University Press: Manchester, UK, 2011; pp. 1-8.

(C) 2013 by the author; licensee MDPI, Basel, Switzerland. This article is an open access article distributed under the terms and conditions of the Creative Commons Attribution license (http://creativecommons.org/licenses/by/3.0/). 